\title{
Effect of Feeding Discarded Dates, Palm Leaves and Its Combination on Growth Performance, Diet Digestibility, Blood Metabolites and Profitability of Ossimi Lambs.
}

\author{
Harby O.H. Galab ${ }^{1}$, Gamal A. El- Sayaad ${ }^{1}$, Ahmed S.M. Soliman' ${ }^{1}$ Hamdy M. A. El-Sayed ${ }^{2}$ Tamer M.M. Hassan ${ }^{\text {* }}$ \\ ${ }^{1}$ Department of Animal Production, Faculty of Agriculture, Benha University, Egypt. \\ ${ }^{2}$ Department of Animal Production, Faculty of Agriculture, Ain Shams University, Egypt. \\ *Corresponding author: tamer.mohamed@,fagr.bu.edu.eg
}

\begin{abstract}
The aim of this study was to investigate the effects of feeding a formulated from local feed sources with using discarded Dates, Palm leaves and its combination on growing Ossemi male lambs growth performance, diet digestibility, blood metabolites and profitability in New Valley Governorate. Forty nine Ossimi male lambs with average body weight $24.82 \mathrm{~kg}$ (4-5 months of age) were divided randomly to seven groups (seven lambs per each group) were fed individually. Frist group lambs were fed the control diet $(0 \%$ discarded Dates and $0 \%$ Palm leaves). The second and third group of lambs were fed an experimental diet contained 7.5 and $15 \%$ of discarded Dates, respectively; the fourth and fifth group of lambs were fed an experimental diet contained 6 and $12 \%$ of Palm leaves, respectively; the sixth group of lambs were fed an experimental diet contained $7.5 \%$ of discarded Dates and 6\% Palm leaves; the seventh group of lambs were fed an experimental diet contained $15 \%$ of discarded Dates and 12\% Palm leaves during 120 days of feeding period. All lambs in each group individually weighed to the nearest gram monthly till the end of experimental period. Animals were housed individually in clean and hygienic pens. Body weight was measured weekly and feed consumption was recorded daily. Digestibility trial was conducted and digestion coefficient was calculated for diet dry matter (DM) and nutrients. At the end of experiment, blood samples were collected for analysis. Economic efficiency (profitability) was evaluated for using discarded Dates, Palm leaves and its combination in the diet. Results showed that there were no significant differences between groups in growth performance parameters between groups. Similar findings were recorded for digestibility of DM and nutrients. Addition of discarded Dates, Palm leaves and its combination in the diets did not negatively affect blood metabolites. Economical profitability was significantly found when feeding $12 \%$ Palm leaves (T4); 15\% discarded Dates and $12 \%$ Palm leaves (T6) in the diet. It can be concluded that discarded Dates, Palm leaves and its combination can be utilized effectively in the diet without adverse effect on growth performance, digestibility blood metabolites of Ossimi lambs.
\end{abstract}

Keywords: discarded Dates, Palm leaves, growth performance, blood metabolites, Ossimi lambs.

\section{Introduction}

Date palms is the major tree crop in Egypt and industry yields large quantities of several by-products which may be used for feeding livestock including low quality dates, date pits and fronds or date palm leaves. Egypt considers the highest country for date production over the world with 1590414 ton (FAO. 2019) around $18 \%$ of the global date production (ElAnsary et al., 2019).

In Egypt there are approximately 20 million date palm trees and in New Valley governorate are 2 million date palm trees (FAO. 2019). Dates Palm loosed during ten-years (2000-2010) at harvesting were $10-15 \%$ and $8.1 \%$ during postharvest processes. This is due to mechanical (harvesting, sorting, grading and transportation) or biological (pests and insects) reasons (El-sayed and Abdel Gleel, 2013). Low quality dates can used in rations of livestock and several studies showed that possibility using it in produce diets for feed livestock (Ahmed et al., 2014). Using date palm in industrial of fodder helps greatly to found vast field for exploited low quality dates, as well as helps in increasing livestock productivity. A date palm tree can produce $13.5-20 \mathrm{~kg}$ of dry fronds annually (Chehma and Longo, 2001; Pascual et al., 2000). This can produce a lot of thousand tons of dry fronds per year. Unfortunately, large quantities of the fronds are not used and being burned by farmers thus causing environmental pollution. Chopped palm fronds have good potential for ruminants while, successfully used date palm fronds as an ingredient of concentrate formulated from local by-products for feeding local sheep (El-Hag and Al-Shargi, 1998; Mahgoub et al., 2007; Al-Suwaiegh, 2016).

This study aimed to investigate the effects of feeding a formulated from local feed sources with using discarded Dates, Palm leaves and its combination on growing Ossemi male lambs growth performance, diet digestibility, blood metabolites and profitability in New Valley Governorate.

\section{Materials and Methods}

The experimental work of this study was carried out in a private sheep farm under supervision of Benha University Animal Production Professors duration time from February to May 2019 at New Valley Governorate, El-Dakhla City at Western Desert, Egypt.

Experimental animals and diets: 
Forty nine Ossimi male lambs with average body weight $24.82 \mathrm{~kg}$ and at $4-5$ months of age were divided randomly to seven groups (seven lambs per each group) were fed individually. Frist group lambs were fed the control diet (0\% discarded Dates and 0\% Palm leaves). The second and third group of lambs were fed an experimental diet contained 7.5 and $15 \%$ of discarded Dates, respectively; the fourth and fifth group of lambs were fed an experimental diet contained 6 and $12 \%$ of Palm leaves, respectively; the sixth group of lambs were fed an experimental diet contained $7.5 \%$ of discarded Dates and 6\% Palm leaves; the seventh group of lambs were fed an experimental diet contained $15 \%$ of discarded Dates and $12 \%$ Palm leaves.
Lambs were subjected to health inspection before the beginning of the trial to ensure that they are in good condition. The experimental lasted 135 days, in which 15 days were considered as a preliminary period, followed by 120 days as an experimental period. The experimental rations were analyzed for $\mathrm{DM}, \mathrm{CP}, \mathrm{CF}$, ADF, NDF, EE and ash content according to AOAC (1995) as showed in Table 1. Feed ingredient components of experimental diets in Table 2 and the chemical composition of experimental diets showed in Table 3. All diets were balanced and designed to meet the nutritional requirements of lambs. Diets of experimental lambs were formulated according to NRC (2007) recommendations for sheep.

Table 1. Chemical analysis of feed stuffs used in experimental diets.

\begin{tabular}{lcccccc}
\hline \multicolumn{1}{c}{ Feed stuffs } & DM\% & CP\% & CF\% & EE & NFE\% & Ash\% \\
\hline Soybean meal & 90.00 & 44.00 & 6.70 & 3.00 & 41.40 & 4.90 \\
Yellow corn & 90.10 & 9.00 & 3.50 & 4.30 & 80.30 & 2.90 \\
Wheat bran & 90.00 & 15.70 & 10.80 & 4.10 & 63.60 & 5.80 \\
Alfafa alfafa & 89.70 & 14.90 & 22.20 & 1.80 & 51.60 & 9.50 \\
Discarded Dates & 83.00 & 5.20 & 2.80 & 0.60 & 85.20 & 6.20 \\
Palm leaves & 92.00 & 3.60 & 36.40 & 1.40 & 46.60 & 12.00 \\
\hline
\end{tabular}

Table 2. Feed ingredient components of experimental diets.

\begin{tabular}{lccccccc}
\hline \multicolumn{1}{c}{ Feed ingredients } & Control & T1 & T2 & T3 & T4 & T5 & T6 \\
\hline Soybean meal & 11.00 & 12.00 & 12.00 & 11.00 & 12.00 & 13.00 & 16.00 \\
Yellow corn & 36.00 & 28.50 & 21.00 & 31.00 & 24.00 & 28.50 & 21.00 \\
Wheat bran & 21.00 & 20.00 & 20.00 & 26.00 & 32.00 & 19.00 & 16.00 \\
Alfafa alfafa & 30.00 & 30.00 & 30.00 & 24.00 & 18.00 & 24.00 & 18.00 \\
Discarded Dates & 0.00 & 7.50 & 15.00 & 0.00 & 0.00 & 7.50 & 15.00 \\
Palm leaves & 0.00 & 0.00 & 0.00 & 6.00 & 12.00 & 6.00 & 12.00 \\
Minerals and & 2.00 & 2.00 & 2.00 & 2.00 & 2.00 & 2.00 & 2.00 \\
vitamins & & & & & & & \\
\hline
\end{tabular}

Table 3. Chemical composition of experimental diets (on \% DM bases).

\begin{tabular}{lcccccccc}
\hline $\begin{array}{c}\text { Experimental } \\
\text { diets }\end{array}$ & DM\% & CP\% & CF\% & NDF & ADF & EE\% & NFE\% & Ash\% \\
\hline Control & 90.15 & 15.85 & 10.92 & 32.21 & 20.53 & 3.28 & 62.29 & 7.66 \\
T1 & 89.62 & 15.85 & 10.83 & 33.17 & 21.32 & 3.00 & 62.45 & 7.87 \\
T2 & 89.08 & 15.56 & 10.78 & 32.04 & 20.95 & 2.72 & 62.81 & 8.15 \\
T3 & 90.28 & 15.51 & 12.15 & 35.41 & 22.56 & 3.28 & 60.75 & 7.96 \\
T4 & 92.03 & 15.57 & 13.47 & 36.84 & 23.75 & 3.19 & 59.04 & 8.31 \\
T5 & 89.75 & 15.47 & 11.64 & 34.52 & 22.12 & 2.96 & 61.32 & 8.05 \\
T6 & 89.36 & 15.33 & 12.33 & 35.77 & 23.08 & 2.62 & 61.31 & 8.41 \\
\hline
\end{tabular}

Lambs growth performance:

All experimental lambs in each group individually weighed to the nearest gram monthly till the end of experimental period (120 days) in the morning before feeding and drinking. Fresh water supply was available along 24 hours. The feed supply was provided twice daily once at 8:00 am and another at 5:00 pm. Both of the consumed diets and refusals, if any, were recorded daily. Total weight gain, average daily weight gain, total and daily feed intake and feed conversion ratio were then calculated.

Digestibility trial:
After three weeks preliminary period, a digestibility trial was carried out for determination of the apparent digestion coefficient (ADC) of diet dry matter (DM) and nutrients. A stainless steel wire mesh was placed on the floor to keep fecal matter away from urine, which was passed through a stream into drainage. Feed intake was daily recorded. Feces were collected, mixed and weighed at morning for successive 7 days then stored at $-20^{\circ} \mathrm{C}$ till analysis. Fecal samples (10\%) were taken daily and dried out at $60^{\circ} \mathrm{C}$ for $48 \mathrm{~h}$ and ground. Feed and fecal samples were analyzed according to AOAC (1995). Dry matter was measured 
using hot air circulation oven (Heraeus Ut20, Germany) at $105{ }^{\circ} \mathrm{C}$ for 3 hours. Crude protein was measured using Kjeltec ${ }^{\circledR}$ system 2100, FOSSSweden. Ether extract (EE) was determined by Soxtec ${ }^{\circledR}$ system 2045, FOSS-Sweden. Crude fiber (CF) was measured using the method of Van Soest et al. (1991) by Fibretherm ${ }^{\circledR}$ system, GerhardtGermany. The ADC of diet was calculated for DM, $\mathrm{CP}, \mathrm{EE}, \mathrm{CF}$ and nitrogen-free extract (NFE) from each dietary treatment using the equation proposed by McDonald et al. (2002).

\section{$\mathrm{ADC} \%$ \\ $=\frac{\text { Total amount of nutrients in feed }- \text { total amount of }}{\text { Total amount of nutrient in feed }}$}

Total amount of nutrients in feed - total amount of nutrients in feces

\section{Blood sampling and analysis:}

Blood samples were taken at the end of the experimental period from 4 lambs of each group in the morning just before feeding. Samples obtained by allowing blood to flow freely from the jugular vein through a clean dry needle into $10 \mathrm{ml}$ test tubes. Blood samples was left at room temperature for $45-65 \mathrm{~min}$ then centrifuged for $30 \mathrm{~min}$ at 4000 r.p.m. Serum was separated into clean dried glass vials $(5-7 \mathrm{ml})$ and stored frozen (-20 C) until analysis. Blood serum was analyzed for serum glucose (Trinder, 1969), serum total protein (Armstrong and Carr, 1964), Serum albumin (Doumas et al., 1971), serum globulin (by subtracting the albumin value from the total protein concentration) serum urea (Patton and Crouch, 1977), serum creatinine, ALT and AST (Reitman and Frankel, 1957).

\section{Economic efficiency (profitability):}

Finance analysis was made to evaluate the production profitability of using discarded Dates, Palm leaves and its combination in diets of experimental lambs. The net return (NR) was calculated according to Sankhyan (1983) from the difference between total income (TI) and total costs
(TC). Total income and total costs were individually calculated for each lamb. The total costs include: the feeding costs (discarded Dates, Palm leaves, its combination and ration), the labor costs (price of a farmer working hour multiplied by the number of hours employed per lamb, veterinary care costs (drugs, vaccines, and veterinary supervision). Water, electricity, equipment maintenance in addition to costs of litter and building rent value were also calculated per lamb for each group. The total income included: income value from final live body weight (lamb). All these parameters were estimated in L.E. over the course of the experiment.

nutrients in feces $\times 100$

\section{Statistical analysis:}

Statistical analysis was carried out by using the least squares procedure for analyzing the data with unequal subclass number described by SAS (2004).

The Statistical model used may be written as follows:

$$
\text { Yij }=\boldsymbol{\mu}+\mathbf{T i}+\mathbf{e i j}
$$

Where: Yij = the observation of growth performance, diet digestibility and blood metabolites for ij lamb; $\mu$ = general mean, common element to all observations; $\mathrm{Ti}=$ the fixed effect due to $\mathrm{I}^{\text {th }}$ treatment groups (i=control, 1, 2, 3, 4, 5, 6). Tests of significance for differences between means were carried out according to Duncan (1955).

\section{Results and Discussions}

\section{Lambs growth performance:}

Results of the final body weight, total weight gain, average daily gain and feed conversion ratio showed a significant improvement $(P<0.05)$ for lambs fed diet contained $7.5 \%$ discarded dates and $6 \%$ Palm leaves (T5) compared with the other treatment groups as showed in Table 4.

Table 4. Growth performance of growing lambs fed the experimental diets.

\begin{tabular}{|c|c|c|c|c|c|c|c|c|c|}
\hline Items & Control & T1 & T2 & T3 & T4 & T5 & T6 & SEM $^{*}$ & P-value \\
\hline Initial body weight, $\mathrm{kg}$ & 25.41 & 25.02 & 24.60 & 24.58 & 24.82 & 24.50 & 24.77 & 0.55 & 0.91 \\
\hline Final body weight, kg & 49.31 & 48.80 & 48.55 & 48.51 & 47.92 & 49.00 & 47.41 & 0.53 & 0.21 \\
\hline Total weight gain, $\mathrm{kg}$ & $23.90^{\mathrm{ab}}$ & $23.68^{\mathrm{bc}}$ & $23.81^{\mathrm{ab}}$ & $23.92^{\mathrm{ab}}$ & $23.10^{\text {cd }}$ & $24.50^{\mathrm{a}}$ & $22.55^{\mathrm{d}}$ & 0.22 & $<0.0001$ \\
\hline Average daily gain, grams & $199^{\mathrm{ab}}$ & $197^{\mathrm{bc}}$ & $198^{\mathrm{ab}}$ & $199^{\mathrm{ab}}$ & $192^{\text {cd }}$ & $204^{\mathrm{a}}$ & $187^{\mathrm{d}}$ & 1.83 & $<0.0001$ \\
\hline Total feed intake of DM, kg & $150.00^{\mathrm{a}}$ & $148.80^{\mathrm{ab}}$ & $147.60^{\mathrm{ab}}$ & $148.80^{\mathrm{ab}}$ & $142.80^{\mathrm{bc}}$ & $153.60^{\mathrm{a}}$ & $139.20^{\mathrm{c}}$ & 2.4 & 0.0009 \\
\hline $\begin{array}{l}\text { Feed conversion ratio } \\
\text { (feed/intake) }\end{array}$ & 6.27 & 6.28 & 6.19 & 6.22 & 6.18 & 6.26 & 6.17 & 0.08 & 0.41 \\
\hline
\end{tabular}

$\overline{\mathrm{a}, \mathrm{b}, \mathrm{c}}$ Within rows means bearing different superscripts differ significantly at $\mathrm{P}<0.05$.

*SEM- Standard error of mean.

The present results of lambs' performance are similar to those obtained by Alhomaidy et al. (2011) and Al-Owaimer et al. (2011) who concluded that the growth performance of Najadi lambs fed on diets containing different dates levels $(0,15$ and $30 \%)$ was significantly $(\mathrm{P}<0.05)$ improved. Also, Hassan et al. (2014) who observed that Awassi lambs fed diet containing $20 \%$ dates and control group had the heavier body weight $(\mathrm{P}<0.05)$ than the other treatment groups.

\section{Apparent digestion coefficient:}

The apparent digestion coefficient $\%$ of dry matter (DM) and nutrients of experimental diets are presented in Table (5). Results showed a significant $(P<0.05)$ difference in digestion coefficient\% of DM, 
crude fiber and acid detergent fiber (ADF) between different experimental groups. It was observed that DM digestibility decreased significantly $(P<0.05)$ for lambs fed $15 \%$ discarded Dates and $12 \%$ Palm leaves (T6) in comparison with the other groups. Crude fiber and ADF digestibility increased significantly $(P<0.05)$ for lambs fed $7.5 \%$ discarded Dates $(\mathrm{T} 1)$ than the other feeding groups. The differences among means of crude protein, neutral detergent fiber (NDF), ether extract and nitrogen free extract (NFE) digestion coefficient $\%$ due to treatment effect were not significant. In a digestibility trial in Awassi lambs performed by Hassan et al. (2014), it was found that the rumen degradability of DM of discarded Dates was better than that of control group. On other spices, Abd El-Rahman et al. (2012) who indicated that digestion coefficient of goats fed on diets containing different levels of cull Dates (0, 10, 20 and 40\%) are not significantly different among all treatments for DM, crude protein, crude fiber, ether extract and NFE.

Table 5. Coefficients of nutrient apparent digestibility (\%) of the experimental lambs

\begin{tabular}{lccccccccc}
\hline \multicolumn{1}{c}{ Items } & Control & T1 & T2 & T3 & T4 & T5 & T6 & SEM $^{*}$ & P-value \\
\hline Dry matter & $66.90^{\mathrm{a}}$ & $66.10^{\mathrm{a}}$ & $66.21^{\mathrm{a}}$ & $65.98^{\mathrm{a}}$ & $66.21^{\mathrm{a}}$ & $66.72^{\mathrm{a}}$ & $64.81^{\mathrm{b}}$ & 0.28 & 0.006 \\
Crude protein & 62.82 & 62.12 & 61.94 & 62.41 & 62.02 & 62.99 & 61.00 & 0.62 & 0.38 \\
Crude fiber & $57.11^{\mathrm{a}}$ & $56.56^{\mathrm{ab}}$ & $55.63^{\mathrm{ab}}$ & $55.16^{\mathrm{ab}}$ & $54.78^{\mathrm{b}}$ & $54.94^{\mathrm{b}}$ & $50.58^{\mathrm{c}}$ & 0.64 & $<0.0001$ \\
$\mathrm{NDF}^{1}$ & 56.82 & 58.41 & 54.79 & 56.15 & 55.69 & 56.39 & 56.64 & 0.90 & 0.26 \\
$\mathrm{ADF}^{2}$ & $54.48^{\mathrm{ab}}$ & $55.51^{\mathrm{a}}$ & $52.41^{\mathrm{c}}$ & $53.04^{\mathrm{bc}}$ & $52.11^{\mathrm{c}}$ & $53.43^{\mathrm{bc}}$ & $53.34^{\mathrm{bc}}$ & 0.62 & 0.01 \\
Ether extract $^{N_{F E}^{3}}$ & 75.51 & 75.93 & 75.00 & 73.45 & 75.46 & 73.80 & 74.97 & 0.74 & 0.22 \\
\hline
\end{tabular}

a,b,c Within rows means bearing different superscripts differ significantly at $\mathrm{P}<0.05$.

*SEM- Standard error of mean

${ }^{1} \mathrm{NDF}=$ Neutral detergent fiber; ${ }^{2} \mathrm{ADF}=$ Acid detergent fiber; ${ }^{3} \mathrm{NFE}=$ Nitrogen free extract.

\section{Blood metabolites:}

Table (6) shows the results of some blood metabolites in the experimental groups. Blood picture and serum biochemistry are important in evaluating the use of non-conventional feed ingredients and their effects on status of animals (Ibrahim et al., 2016). Blood glucose level was found to significantly $(P<0.05)$ raised with increasing discarded Dates level in the diet. Presence of soluble carbohydrates and digestible nutrients in the diet could increase blood glucose level (Abdollahzadeh et al., 2010). Serum levels of proteins and albumin are valuable in reflecting the health of hepatic cells. Serum protein, albumin, globulin, ALT, creatinine, uric acid and total cholesterol values (Table 6) of lambs fed 7.5\% discarded Dates and 6\% Palm leaves (T5) significantly $(\mathrm{P}<0.05)$ higher than the other feeding groups. The values in this study were in the normal range indicating no anti-nutritional factors that might reduce nutrient absorption in the small intestine, proposing intact hepatocellular functions. Similar results was concluded by Shrdh et al. (2016) and Azzaz et al. (2017) who reported that using discarded dates in rations have no marked effects on serum concentrations.

Table 6. Blood metabolites of growing lambs fed the experimental diets.

\begin{tabular}{|c|c|c|c|c|c|c|c|c|c|}
\hline Items & Control & T1 & T2 & T3 & T4 & T5 & T6 & SEM $^{*}$ & P-value \\
\hline Glucose (mg/dl) & $135.0^{c}$ & $149.5^{\mathrm{b}}$ & $169.5^{\mathrm{a}}$ & $126.8^{\mathrm{cd}}$ & $122.6^{\mathrm{d}}$ & $135.9^{c}$ & $134.3^{\mathrm{c}}$ & 2.89 & $<0.0001$ \\
\hline $\begin{array}{l}\text { Total protein } \\
\text { (g/dl) }\end{array}$ & $6.35^{\mathrm{b}}$ & $6.31^{\mathrm{b}}$ & $5.92^{\mathrm{c}}$ & $5.41^{\mathrm{d}}$ & $4.86^{\mathrm{e}}$ & $7.01^{\mathrm{a}}$ & $4.69^{e}$ & 0.11 & $<0.0001$ \\
\hline Albumin (g/dl) & $3.22^{\mathrm{b}}$ & $3.34^{\mathrm{b}}$ & $3.75^{\mathrm{a}}$ & $3.19^{\mathrm{b}}$ & $2.71^{\mathrm{c}}$ & $3.81^{\mathrm{a}}$ & $2.39^{d}$ & 0.06 & $<0.0001$ \\
\hline Globulin (g/dl) & $3.13^{\mathrm{a}}$ & $2.96^{\mathrm{a}}$ & $2.17^{\mathrm{b}}$ & $2.21^{\mathrm{b}}$ & $2.15^{\mathrm{b}}$ & $2.20^{\mathrm{a}}$ & $2.30^{\mathrm{b}}$ & 0.09 & $<0.0001$ \\
\hline $\mathrm{A} / \mathrm{G}$ ratio & $1.03^{\mathrm{d}}$ & $1.14^{\mathrm{cd}}$ & $1.72^{\mathrm{a}}$ & $1.44^{\mathrm{b}}$ & $1.25^{\mathrm{c}}$ & $1.19^{c}$ & $1.04^{\mathrm{d}}$ & 0.04 & $<0.0001$ \\
\hline $\operatorname{ALT}(\mathbf{U} / \mathbf{L})^{1}$ & $20.30^{\mathrm{bc}}$ & $20.28^{\mathrm{bc}}$ & $20.77^{\mathrm{a}}$ & $20.50^{\mathrm{b}}$ & $20.52^{\mathrm{b}}$ & $20.29^{b c}$ & $20.18^{c}$ & 0.07 & 0.0005 \\
\hline $\operatorname{AST}(\mathbf{U} / \mathbf{L})^{2}$ & 34.37 & 34.80 & 34.47 & 34.62 & 33.83 & 35.06 & 33.95 & 0.33 & 0.16 \\
\hline $\begin{array}{l}\text { Creatinine } \\
\text { (mg/dl) }\end{array}$ & $0.83^{\mathrm{cd}}$ & $0.86^{\mathrm{c}}$ & $0.97^{\mathrm{a}}$ & $0.84^{\mathrm{cd}}$ & $0.81^{\mathrm{cd}}$ & $0.95^{\mathrm{a}}$ & $0.75^{\mathrm{d}}$ & 0.03 & $<0.0001$ \\
\hline Uric acid (mg/dl) & $40.14^{\mathrm{d}}$ & $44.58^{\mathrm{cd}}$ & $45.66^{\mathrm{b}}$ & $42.35^{\mathrm{cd}}$ & $46.82^{\mathrm{b}}$ & $49.53^{\mathrm{a}}$ & $42.45^{\mathrm{cd}}$ & 0.78 & $<0.0001$ \\
\hline $\begin{array}{l}\text { Total cholesterol } \\
\text { (mg/dl) }\end{array}$ & $80.96^{\mathrm{bc}}$ & $77.30^{\text {de }}$ & $78.54^{\text {cde }}$ & $76.55^{\mathrm{e}}$ & $82.25^{\mathrm{b}}$ & $80.57^{\mathrm{bcd}}$ & $87.08^{\mathrm{a}}$ & 1.07 & $<0.0001$ \\
\hline
\end{tabular}

$\overline{\mathrm{a}, \mathrm{b}, \mathrm{c}}$ Within rows means bearing different superscripts differ significantly at $\mathrm{P}<0.05$.

*SEM- Standard error of mean

${ }^{1} \mathrm{AST}$ - Aspartate transaminase

${ }^{2} \mathrm{ALT}$ - Alanine transaminase 
Economic efficiency (profitability):

Data of costs, income and net return are shown in Table 7. The total costs (TC) of lambs fed control diet higher (2075.70 L.E./animal) than TC of lambs fed T1, T2, T3, T4, T5 and T6 diets $(2029.14,2011.81$, 1891.01, 1879.85, 1976.15 and 1858.15 L.E./animal, respectively). Net profit was higher $(559.46,564.81$, 652.35, 693.67, 622.85 and 657.51 L.E./animal, respectively) for lambs fed $\mathrm{T} 1, \mathrm{~T} 2, \mathrm{~T} 3, \mathrm{~T} 4, \mathrm{~T} 5$ and $\mathrm{T} 6$ diets than that for lambs fed control diet $(538.90$ L.E./animal). Financial analysis of the T1, T2, T3, T4,
T5 and T6 feeding groups earned about 20.56, 25.91, $113.45,154.77,83.95$ and 118.61 L.E./lamb, respectively, more profit than the control feeding group. Therefore, results of the present study showed that feeding lambs discarded Dates, Palm leaves and its combination in different levels increases profitability. These results agree with those of Abd El-Rahman et al. (2012) who found that feeding kids cull Dates in different levels $(0,50,75$ and 100\%) increased net feed revenue and economic feed efficiency.

Table 7. Economic efficiency (profitability) of growing lambs fed the experimental diets.

\begin{tabular}{lccccccc}
\hline Items & Control & T1 & T2 & T3 & T4 & T5 & T6 \\
\hline Ration cost (L.E./ton) & 3486 & 3328 & 3183 & 2572 & 2479 & 3055 & 2427 \\
Equipment depreciation & 32.70 & 32.70 & 32.70 & 32.70 & 32.70 & 32.70 & 32.70 \\
$\begin{array}{l}\text { (L.E./animal) } \\
\text { Building depreciation }\end{array}$ & 21.40 & 21.40 & 21.40 & 21.40 & 21.40 & 21.40 & 21.40 \\
(L.E./animal) & & & & & & & \\
Water and electricity & 19.60 & 19.60 & 19.60 & 19.60 & 19.60 & 19.60 & 19.60 \\
(L.E./animal) & & & & & & & \\
Veterinary management & 36.70 & 36.70 & 36.70 & 36.70 & 36.70 & 36.70 & 36.70 \\
(L.E./animal) & & & & & & & \\
Labor cost (L.E./animal) & 147.00 & 147.00 & 147.00 & 147.00 & 147.00 & 147.00 & 147.00 \\
Total fixed cost (L.E./animal) & 257.40 & 257.40 & 257.40 & 257.40 & 257.40 & 257.40 & 257.40 \\
Purchased lambs (L.E./animal) & 1295.40 & 1276.53 & 1254.60 & 1266.33 & 1253.58 & 1249.50 & 1263.27 \\
Feed cost (L.E./animal) & 522.90 & 495.21 & 469.81 & 367.28 & 368.87 & 469.25 & 337.84 \\
Total variable cost & 1818.30 & 1771.74 & 1754.41 & 1633.61 & 1622.45 & 1718.75 & 1601.11 \\
(L.E./animal) & & & & & & & \\
Total costs (L.E./animal) & 2075.70 & 2029.14 & 2011.81 & 1891.01 & 1879.85 & 1976.15 & 1858.51 \\
Sheep sales (L.E./animal) & 2563,60 & 2537.60 & 2525.12 & 2492.36 & 2522.52 & 2548.00 & 2464.80 \\
Wool sales (L.E./animal) & 24.00 & 24.00 & 24.00 & 24.00 & 24.00 & 24.00 & 24.00 \\
Litter sales (L.E./animal) & 27.00 & 27.00 & 27.00 & 27.00 & 27.00 & 27.00 & 27.00 \\
Total returns (L.E./animal) & 2614,60 & 2588.60 & 2576.12 & 2543.36 & 2573.52 & 2599.00 & 2515.80 \\
Net profit (L.E./animal) & 538.90 & 559.46 & 564.81 & 652.35 & 693.67 & 622.85 & 657.29 \\
\hline & & & & & & &
\end{tabular}

\section{Conclusion}

The finding of this study showed that discarded Dates, Palm leaves and its combination can be fed to Ossimi lambs with no detrimental effects on growth performance, nutrients digestibility and blood metabolites. Palm leaves and discarded Dates could be suitable from now on as an economic perspective due to their low prices and large availability; although the costs of the other supplements may compensate the benefit of these two feeds.

\section{References}

Abdel-Rahman, h.h.; Abedo, A.A.; El-Nomeary, Y.A.A.; Shoukry, M.M.; Mahamed, M.I. and Mona, S. Zaki. (2012) Response of replacement of yellow corn with cull dates as a source of energy on productive performance of goats kids. Life Sciences Journal Vol. 9 (4):2250-2255.

Abdollahzadeh, F.; Pirmohammadi, R.; Farhoomand, P.; Romero-Huelva, M.; Ramos-
Morales, E.; Fatehi, E.F. and Pazhoh, F.F. (2010). The effect of ensiled Molina-Alcaide, 2012. Nutrient utilization, ruminal mixed tomato and apple pomace on Holstein dairy fermentation, microbial abundances and milk yield cow. Ital. J Anim. Sci., Vol. 9: 212-216.

Ahmed, A.A.; Hassan, M.J. and Al-Jadoui (2014) Effect of substitution low quality Zahdi date in rations instead of barley on Awassi sheep performance. The Iraqi Journal Agricultural Sciences. 45(4):359-367.

Alhomidy, S.N.; Basmaeil, S.; Al- Owaimer, A.N.; El-Waziry, A.M. and Koohmaraie, M. (2011) Effect of feeding different amounts of discarded dates on growth and efficiency of digestion in sheep. Australian Journal of Basic and Applied Sciences Vol. 5(3): 636-640.

Al-Owaimer, A.N.; El-Waziry, A.M.; Koohmaraie, M. and Zahran, S.M. (2011) The use of ground date pits and Atriplex halimus as alternative feeds for sheep. Australian Journal of Basic and Applied Sciences, Vol. 5(5):1154-1161. 
Al-Suwaiegh, S.B (2016) Effect of substituting different levels of date pits and urea treated palm leaves on growth performance and nutrients digestibility of Ardi goats. Research Journal of Veterinary Sciences. Vol. 10:1-8.

AOAC (1995). Official Methods of Analysis of the Association of Official Analytical Chemists, $16^{\text {th }}$ edition.

Armstrong, W.D. and Carr, C.W. (1964). Physiological chemistry: Laboratory direction $3^{\text {rd }}$ ed. Pp. 75, Burges publishing Co., Minnea-Polis, Minnesota.

Azzaz, H. H.; Eman Farahat, S.A. and Ebeid, H.M. (2017) Effect of partial replacement of corn grains by dates seeds on Rahmani ram's nutrients digestibility and Nubian goat's milk production. International Journal of Dairy Science Vol. 12(4):266-274.

Chehma A. and Longo H.F. (2001). Bilan azote et gain de poids, chez le dromadaire et le mouton, alimentes a base de sous-produits du palmier dattier, de la pailled'orge et du drinnAristidapungens. Cahiers Agricultures. Vol. 13(2): 221-226.

Doumas, B. T.; Watson, W. A. and Biggs, H. G. (1971). Colorimetric determination of albumin. Clin. Chem. Acta, 31: 87.

Duncan, D.B. (1955). Multiple ranges and multiple Ftest. Biometrics. 11, 1-42.

El-Ansary, M.A.; Omar, A.K.; Salama, A. and Helal, S.M. (2019). Assessment of fruit defects and economic loss of some soft date palm cultivars (Phoenix Dactylifera L.) in north delta, Egypt. Applied Ecology and Environmental Research Vol. 17(3):5965-5974.

El Hag, M.G. and Al Shargi, K.M. (1998). Comparative performance of goats and sheep fed on high- fiber pelleted diets supplemented with different nitrogen sources. Journal Applied Animals Research 13: 179-184

El-Sayed, E. A. and Abdel Gleel, S. S. (2013). An economic analysis for production and exports of date in Egypt. - J. Agric. Econom. Social Sci., Mansoura Univ. Vol. 4(9): 1771- 1783.

FAO (2019). Strategy for the Development of Date Palm and Dates Sector in Egypt. http://www.fao.org/egypt/resources/ar/.

Hassan, Sh.A. and Abass, I.R. (2014) Effect of substitution date by barley with two sources of nitrogen on intake, live weight gain, feed conversion ratio and digestion coefficients. The
Iraqi Journal Agricultural Sciences. Vol. 45(6):555-565.

Ibrahim, O.A.; Hyacinth, A.A.; Terzungwe, A. and Danie, O.L. (2016). Growth performance, hematological and serum biochemical profiles of West African Dwarf goats fed dietary guava leaf meal. International Journal of Agriculture and Biosciences. Vol. 5(4): 188-191.

Mahgoub, O.; Kadim I.T.; Al-Busaidi, M.H.; Annamali, K. and Al-Saqri, N.M. (2007). Effect of feeding ensiled date palm fronds and a byproduct concentrate on performance and meat quality of Omani sheep. Animal Feed Science and Technology Vol. 135: 210-221.

McDonald, P.; Edward R.A.; Greenhalgh J.F.D. and Morgan G.A. (2002). Animal Nutrition 6th ed. Pearson Educational Limited. Edinburgh, Great Britain. PP 544.

NRC (2007). Nutrient Requirements of Small Ruminant. National Academy Press, Washington, DC.

Pascual, J.J.; Fernandez, C; Diaz, J.R.; Garces, C and Rubert-Aleman, J. (2000). Voluntary intake and in vivo digestibility of different date-palm fractions by Murciano- Granadina (Capra Hircus). J. Arid Environ. 45: 183-189.

Patton, C. J. and Crouch, S. R. (1977). Spectrophotometric and kinetics investigation of the Berthelot reaction for the determination of ammonia. Analytical Chemistry, 49: 464-469.

Reitman, S. and Frankel, S. (1957). A Colorimetric Method for the Determination of Serum Glutamic Oxalacetic and Glutamic Pyruvic transaminases. American Journal of Clinical Pathological, 28: 56-63.

Sankhyan, L.P. (1983). Introduction to farm management. Tata MC-Grow Hill Publishing Company Limited, New Delhi.

SAS (2004). SAS Procedure Guide" version 9 Ed". SAS Institute Inc., Cary, NS, USA.

Shrdh, I.A.; Amaizik, S.A. and Milad, I.S. (2016) Evaluation of discarded dates on the performance of Libyan local goats. Al Mukhtar Journal of Sciences Vol. 31(1):60-72.

Trinder, P. (1969). Determination of glucose in blood using glucose oxidase with an alternative oxygen acceptor. Ann. Clin. Biochem. 6, 24-27.

Van Soest, P.J.; Robertson J.B. and Lewis B.A. (1991). Methods for dietary fiber, neutral detergent fiber and non-starch polysaccharides in relation to animal nutrition. J. Dairy Sci., vol. 74, p. 3583-3597. 


\section{تأثير أستخدم البلح المستبعد وأورلق النخيل والخليط بينهما على أداء النمو وهضم الغذاء ومكونات الام والكفاءة الأقتصادية فى حملان الأوسيمى

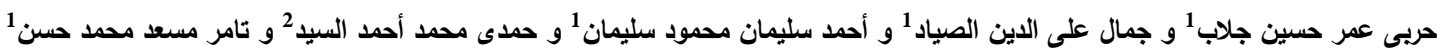

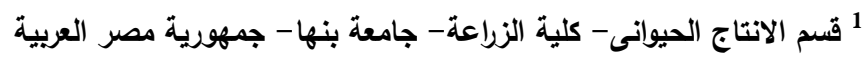 \\ 2 قسم الانتاج الحيوانى- كلية الزراعة- جامعة عين شمس - جمهورية مصر العربية}

تم أجراء هذا البحث لدراسة نأثثر البلح المستبد وأوراق النخيل والخليط بينهما على أداء النمو وهضم الغذاء ومكونات الدم والكفاءة الأقتصادية

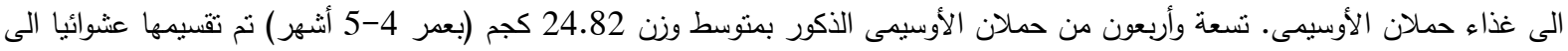
سبعة مجموعات أختبارية (سبعة حملان بكل مجموعة). كانت المجموعة الأولى المقارنة تتخذى على عليقة خالية من البلح المستبعد وأوراق النخيل والمجموعة الثانية والثالثة كانت تتخذى على عليقة تحنوى على 7.5 و 15 \% بلح مستبعد على التنتيب و المجموعة الرابعة والخامسة كانت تتخذى 6لى عليقة تحتوى على 6 و 12 \% أوراق نخيل على الترتيب و المجموعة السادسة كانت تتخذى على عليقة تحتوى على 7.5 \% بلح مستبعد و 6\% أوراق نخيل والمجموعة السابعة كانت تتخذى على 15\% بلح مستبعد و 12\% أوراق نخيل لمدة 120 يوم. تم أيواء الحيوانات بشكل فردى فى

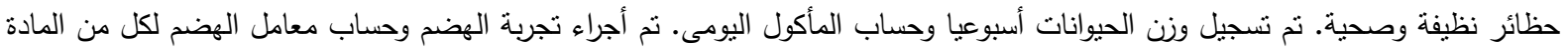

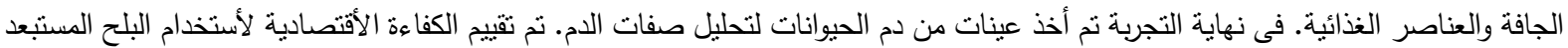
وأوراق النخيل والخليط بينهما فى غذاء الأغنام. أظهرت النتائج عدم وجود فروق معنوية بين مجموعات التجربة على أداء النمو . نفس النتائج تم تسجيلها لنقدير معامل الهضم للمادة الجافة والعناصر الغذائية. أظهرت الننائج أن أضافة البلح المستبعد وأوراق النخيل والخليط بينهما لغذاء الحملان لم يؤثر سلبا على مكونات النات الدم. بينما

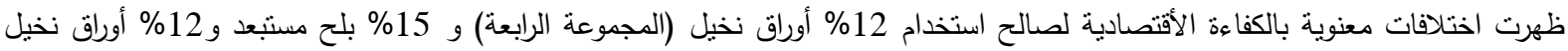
(المجموعة السادسة) فى غذاء الحيوانات. نخلص من ذلك الى أن البلح المستبعد وأوراق النخيل والخليط بينهما يمكن أستخدامه بشكل فعال فى النظام الغذائى دون تأثير سلبى على أداء النمو والهضم ومكونات الام لحملان الأوسيمى. 